Jurnal THEOREMS (The Original Research of Mathematics) Vol. 4 No. 2, Januari 2020. hal. 213-218

URL: http://jurnal.unma.ac.id/index.php/th

Naskah masuk: 27-12-2019 Naskah diperbaiki: 02-01-2020 Naskah diterima: 03-01-2020

\title{
ANALISIS KESULITAN BELAJAR MAHASISWA FAPERTA PADA MATA KULIAH MATEMATIKA DASAR
}

\section{ANALYSIS OF LEARNING DIFFICULTIES OF FAPERTA STUDENTS IN BASIC MATHEMATICS}

\author{
Tri arif Wiharso \\ Prodi Teknik Telekomunikasi, Fakultas Teknik, UNIGA, Jl. Jati 42b, 44151, Indonesia \\ E-mail: triarifw@gmail.com
}

\begin{abstract}
ABSTRAK
Kesulitan mahasiswa dalam menyelesaikan persoalan matematis menjadi suatu petunjuk sejauh mana mahasiswa menguasai materi matematika. Penelitian ini bertujuan untuk mengetahui faktor-faktor kesulitan belajar mahasiswa pada mata kuliah matematika dasar. Subjek dalam penelitian ini yaitu mahasiswa semester I sebanyak 86 mahasiswa dari prodi agroteknologi fakultas Pertanian di salah satu perguruan tinggi di Garut. Metode yang digunakan melalui pendekatan kualitatif dengan teknik pengumpulan data dari hasil tes tertulis. Instrumen yang digunakan dalam penelitian dengan pemberian soal tertulis . Hasil yang didapat dari penelitian ini 1) Mahasiswa kesulitan dalam merubah desimal kedalam pecahan karena kurangnya pemahaman terhadap materi dan lemahnya konsep dasar matematika seperi perkalian puluhan dengan desimal. 2) Mahasiswa kurang memahami sifatsifat perpangkatan dan bilangan irasional dalam menyelesaikan masalah mengenai domain dan range fungsi. 3) Lemahnya konsep turunan dengan menerapkan definisi limit fungsi. 4) Mahasiswa keliru dalam menentukan rumus turunan antara turunan perkalian dengan turunan pembagian.
\end{abstract}

Kata kunci: Kesulitan belajar, Matematika Dasar

\section{ABSTRACT}

The difficulty of students in solving mathematical problems becomes an indication of the extent to which students master mathematical material. This study aims to determine the factors of student learning difficulties in elementary mathematics courses. The subjects in this study were 86 first semester students of agrotechnology study programs at the Faculty of Agriculture at one of the universities in Garut. The method used through a qualitative approach with data collection techniques from the results of written tests. The instrument used in research by giving written questions. The results obtained from this study 1) Students have difficulty in converting decimals into fractions due to lack of understanding of the material and weak basic mathematical concepts such as multiplication of tens with decimals. 2) Students lack understanding of the properties of ranks and irrational numbers in solving problems regarding domains and range of functions. 3) Weak derivative concepts by applying the definition of a limit function. 4) Students err in determining the derivative formula between multiplication and division derivatives.

Keywords: learning difficulties, basic mathematic] 


\section{PENDAHULUAN}

Matematika mempunyai peranan dalam memberikan pengalaman berpikir kritis, analisis dan sistematis yang berguna dalam membedah masalah secara rasional. sejalan dengan itu, NCTM menjelaskan bahwa "mathematics learning is both about making sense of mathematical ideas and about acquir-ing skills and insights to solve problems" [1]. Dari kutipan tersebut mengandung makna bahwa matematika dapat menimbulkan rasa ide-ide matematika dan menciptakan keterampilan dan pengetahuan dalam memecahkan masalah. Pendapat lainnya menyatakan bahwa "matematika itu penting baik sebagai alat bantu, sebagai ilmu (bagi ilmuan), sebagai pembentuk sikap maupun pembentuk pembimbing pola pikir" [2].

Makanya tidak heran jika matematika diajarkan di semua jenjang seperti di perguruan tinggi, tak terkecuali di fakultas pertanian dimana matakuliah matematika dasar diberikan supaya mahasiswa mempunyai wawasan mengenai matematika dan mampu mengaplikasikan untuk analisis perhitungan dalam bidang pertanian. Selain itu, mata kuliah matematika dasar di Fakultas Pertanian terkait dengan matakuliah lainnya Seperti matakuliah statistika dan matakuliah rancangan percobaan.

Namun permasalahan muncul bahwa mahasiswa menunjukkan hasil yang kurang bagus dalam matakuliah matematika dasar berdasarkan hasil observasi di fakultas pertanian di Garut bahwa hasil Ujian UTS dan UAS tahun 2018/2019 rata-ratanya di bawah 50, sama halnya pada tahun sebelumnya yang memperlihatkan kemampuan matematikanya masih rendah.

Hasil belajar yang rendah tersebut mengindikasikan bahwa mahasiswa mengalami kesulitan dalam menyelesaikan persoalan matematika, persoalan tersebut berkaitan dengan pemberian soal matematika yang tidak dapat di pecahkan dengan benar oleh mahasiswa. karena itu, perlunya analisis mengenai kesulitan belajar mahasiswa pada matakuliah matematika dasar. Kesulitan belajar merupakan kurang berhasilnya siswa dalam menguasai konsep, prinsip, atau algoritma penyelesaian masalah [3].

Selanjutnya dalam matematika Konsep, prinsip dan algoritma merupakan hal yang penting karena merupakan suatu rangkaian dalam pemecahan masalah matematika. Seperti yang tetulis dalam permendiknas nomor 22 tahun 2006 bahwa salah satu tujuan pembelajaran matematika agar peserta didik mampu memahami konsep matematika, menjelaskan keterkaitan antar konsep dan mengaplikasikan konsep atau algoritma secara luwes, akurat, efisien, dan tepat dalam pemecahan masalah.

Dengan demikian berdasarkan paparan sebelumnya, tujuan penelitian ini yaitu untuk mengetahui faktorfaktor kesulitan belajar mahasiswa pada mata kuliah matematika dasar di fakultas Pertanian di Garut, supaya hasil analisis ini bisa digunakan untuk langkah perbaikan hasil belajar mahasiswa kedepannya.

\section{METODE PENELITIAN}

Penelitian ini merupakan penelitian kualitatif dengan teknik pengumpulan data dengan cara tes. Instrumen yang digunakan dalam penelitian dengan pemberian soal tertulis. Dengan materi sistem bilangan riil, fungsi dan turunan dengan jumlah 6 butir soal . subjek dalam penelitian ini yaitu mahasiswa semester I tahun akademik 2019/2020 fakultas pertanian dari Prodi agroteknologi sebanyak 86 mahasiswa di salah satu PTS di garut

Copyright $(20 \mathrm{xx}$, Jurnal THEOREMS (The Original Research of Mathematics) p-ISSN: 2528-102X, e-ISSN: 2541-4321, URL: http://jurnal.unma.ac.id/index.php/th 
pengambilan subjek dilakukan dengan pertimbangan mewakili mahasiswa prodi yang lainnya yang dianggap mempunyai kemampuan yang sama, berdasarkan data yang diambil dari hasil wawancara dengan dosen pengampu mata kuliah matematika dasar.

Instrumen soalnya sebagai berikut :

1. Ubahlah bilangan 3,9292929292 menjadi bentuk pecahan.

2. Tentukan Domain dan range dari fungsi $f(x)=\sqrt{x}-1$ dengan $-4<$ $x \leq 1$, dengan $x \in \mathbb{Z}$

3. Dengan menggunakan $f^{\prime}(x)=$ $\lim _{h \rightarrow 0} \frac{f(x+h)-f(x)}{h}$, carilah turunan pertama dari $f(x)=2 x^{2}-3 x-1$

4. Carilah turunan pertama dari $y=$ $\frac{2 x^{4}-1}{\sqrt{3}+x}$

5. Carilah turunan pertama dari $y=$ $\frac{1}{4} x^{3}-\frac{5}{x^{2}}+2 \sqrt{x}$

\section{HASIL DAN PEMBAHASAN}

Hasil tes soal yang diberikan setelah pembelajaran sebanyak lima soal kepada mahasiswa tersaji dalam tabel 1 berikut ini :

Tabel 1.

Hasil Tes Matematika

\begin{tabular}{|c|c|c|c|}
\hline $\begin{array}{l}\text { Nomor } \\
\text { soal }\end{array}$ & $\begin{array}{l}\text { Skor } \\
\text { ideal }\end{array}$ & $\begin{array}{l}\text { Rata- } \\
\text { Rata }\end{array}$ & $\begin{array}{l}\text { Persentase } \\
(\%)\end{array}$ \\
\hline 1 & \multirow{5}{*}{4} & 1.77 & 44.19 \\
\hline 2 & & 1.66 & 41.57 \\
\hline 3 & & 1.44 & 36.05 \\
\hline 4 & & 1.58 & 39.53 \\
\hline 5 & & 1.80 & 45.05 \\
\hline \multicolumn{2}{|c|}{ Rata-rata } & 1.62 & 40.55 \\
\hline
\end{tabular}

Dari hasil tabel 1 terlihat soal yang banyak salah pengerjaannya yaitu soal nomor 3 dan yang kedua soal nomor 4, berturut-turut diikuti oleh nomor 2, nomor 1 dan nomor 5 dengan rata-rata skor 1.62 dan rata-rata persentase 40.55 , dilihat dari hasil ini menunjukkan bahwa kemampuan mahasiswa masih rendah.

Dari 5 soal yang diberikan dari materi sistem bilangan, fungsi dan turunan dianalisis kesalahan jawaban mahasiswa dengan mengambil sampel beberapa kesalahan yang sering muncul.

\section{Analisis kesalahan soal nomor 1}

Tabel di bawah ini merupakan hasil pengerjaan soal nomor satu dari 86 mahasiswa

Tabel 2.

Deskripsi Kesalahan Soal Nomor 1

\begin{tabular}{|l|c|}
\hline Deskripsi kesalahan & persentase \\
\hline $\begin{array}{l}\text { Tidak ada satupun } \\
\text { langkah yang benar }\end{array}$ & 9.30 \\
\hline Salah mengalikan & 34.88 \\
\hline $\begin{array}{l}\text { Sudah benar mengalikan } \\
\text { tapi keliru pada tahap } \\
\text { mengurangkan }\end{array}$ & 33.72 \\
\hline $\begin{array}{l}\text { Sudah bisa merubah ke } \\
\text { bentuk pecahan tetapi ada } \\
\text { kesalahan tanda }\end{array}$ & 13.95 \\
\hline Tidak ada kesalahan & 8.14 \\
\hline
\end{tabular}

Hasil sebagian kesalahan pengerjaan mahasiswa terlihat dari gambar berikut

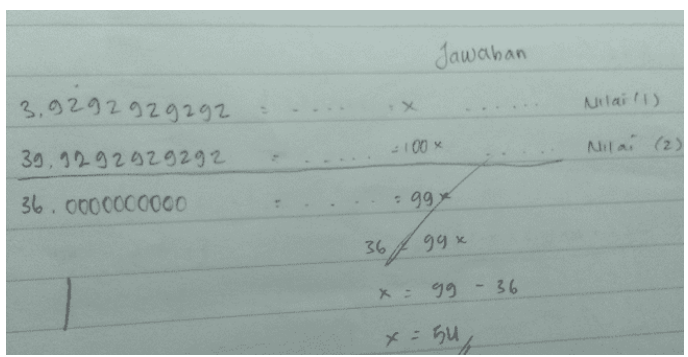

Gambar 1.

Kesalahan Jawaban Sebagian Mahasiswa Soal Nomor 1

Pada gambar 1. Terlihat bahwa kesalahan dasar pada proses mengalikan dengan 3.92929292 dengan 10 yang harusnya dikalikan dengan 100 di soal nomor satu ini, kesalahan sering 
Jurnal THEOREMS (The Original Research of Mathematics) Vol. 4 No. 2, Januari 2020. hal. 213-218

URL: http://jurnal.unma.ac.id/index.php/th

Naskah masuk: 27-12-2019 Naskah diperbaiki: 02-01-2020 Naskah diterima: 03-01-2020

terjadi pada seperti ini, sebagian lagi kesalahan dalam hasil menjumlahkan antara persamaan yang sudah dikalikan dengan persamaan yang di bawahnya.

Analisis kesalahan soal nomor 2

Tabel 3.

Deskripsi Kesalahan Soal Nomor 2

\begin{tabular}{|c|c|c|}
\hline & Persentase \\
\hline \multicolumn{2}{|c|}{$\begin{array}{l}\text { Tidak ada satupun } \\
\text { langkah yang benar }\end{array}$} & 11.63 \\
\hline $\begin{array}{l}\text { Kesalahan } \\
\text { sebagaian } \\
\text { domian }\end{array}$ & $\begin{array}{r}\text { dalam } \\
\text { jawaban }\end{array}$ & 33.72 \\
\hline $\begin{array}{l}\text { Kesalahan } \\
\text { mengakarkan } \\
\text { negatif }\end{array}$ & $\begin{array}{r}\text { dalam } \\
\text { bilangan }\end{array}$ & 46.51 \\
\hline Tidak ada kesale & & 8.14 \\
\hline
\end{tabular}

hasil sebagian kesalahan pengerjaan mahasiswa terdapat dalam gambar 2 .

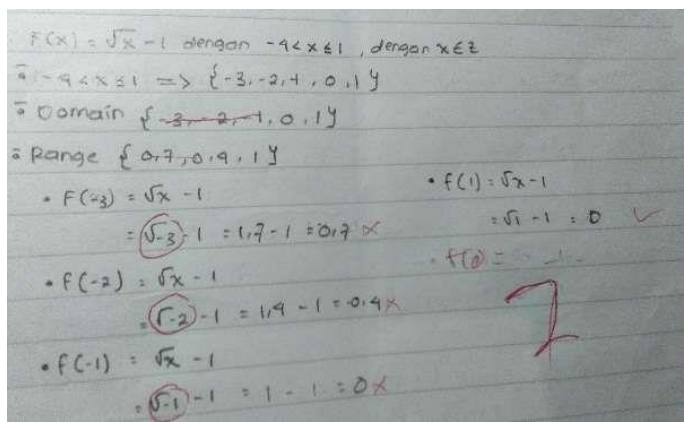

Gambar 2.

Kesalahan Jawaban Mahasiswa Soal Nomor 2

Dari gambar 2 terlihat kesalahan pengerjaan terletak pada pengakaran dimana akar dari angka negatif menghasilkan suatu nilai, padahal nilai akar dari angka negatif tidak terdefinisi. Banyak mahasiswa yang mengisi seperti itu, dengan demikian dapat disimpulkan bahwa mereka kurang memahami sifat perpangkatan dan bilangan irasional. $\underline{\text { Analisis kesalahan soal nomor } 3}$

Tabel 4.

Deskripsi Kesalahan Soal Nomor 3

\begin{tabular}{|l|c|}
\hline Deskripsi kesalahan & persentase \\
\hline $\begin{array}{l}\text { Tidak ada satupun } \\
\text { langkah yang benar }\end{array}$ & 5.81 \\
\hline $\begin{array}{l}\text { Kesalahan dalam hasil } \\
2(x+h)^{2}-3(x+h)-1\end{array}$ & 48.84 \\
\hline $\begin{array}{l}\text { Kesalahan pada ketidak } \\
\text { telitian dalam oprasi }\end{array}$ & 41.86 \\
\hline Tidak ada kesalahan & 2.33 \\
\hline
\end{tabular}

Selanjutnya hasil sebagian kesalahan pengerjaan mahasiswa untuk nomor 3 terlihat dari gambar 3 berikut

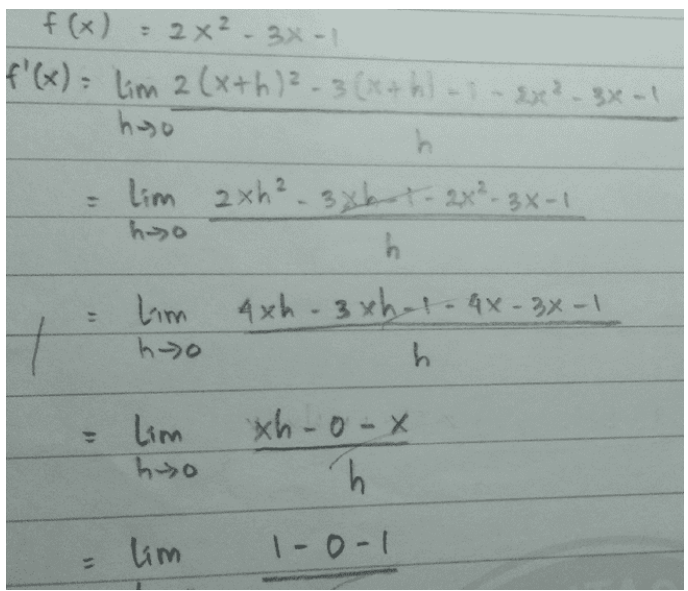

Gambar 3.

\section{Kesalahan Jawaban Mahasiswa Soal} Nomor 3

Pada soal nomor tiga mahasiswa banyak yang keliru dalam proses $(\mathrm{x}+$ $h)^{2}-3(x+h)-\left(2 x^{2}-3 x-1\right)$ mereka seperti kebingungan dalam menyelesaikannya, padahal tahap memasukkan fungsi terhadap rumus sudah benar, hasil pengerjaannya bisa terlihat dari gambar 3. 


\section{Analisis kesalahan soal nomor 4}

\section{Tabel 5.}

Deskripsi Kesalahan Soal Nomor 4

\begin{tabular}{|l|c|}
\hline Deskripsi kesalahan & persentase \\
\hline $\begin{array}{l}\text { Tidak ada satupun } \\
\text { langkah yang benar }\end{array}$ & 9.30 \\
\hline Rumusan yang keliru & 82.56 \\
\hline Tidak ada kesalahan & 3.49 \\
\hline
\end{tabular}

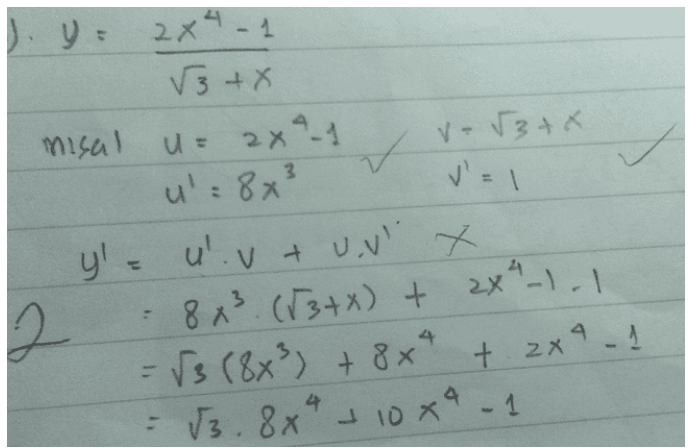

Gambar 4.

\section{Kesalahan Jawaban Mahasiswa Soal} Nomor 4

Terlihat dari gambar nomor 4 kesalahan terdapat pada proses memasukan rumus yang seharusnya menggunakan rumus pembagian turunan bukan rumus perkalian turunan, banyak yang mengerjakan seperti ini, kesalahan yang lainnya mahasiswa banyak yang keliru dalam mengoprasikan setelah dimasukan pada rumusnya.

\section{Analisis kesalahan soal nomor 5}

\section{Tabel 6.}

\section{Deskripsi Kesalahan Soal Nomor 5}

\begin{tabular}{|l|c|}
\hline Deskripsi kesalahan & persentase \\
\hline $\begin{array}{l}\text { Tidak ada satupun } \\
\text { langkah yang benar }\end{array}$ & 8.14 \\
\hline $\begin{array}{l}\text { Tidak bisa menyelesaikan } \\
\text { turunan pada bagian } \\
-\frac{5}{\mathrm{x}^{2}}+2 \sqrt{x}\end{array}$ & 69.77 \\
\hline Tidak ada kesalahan & 15.12 \\
\hline
\end{tabular}

Hasil pengerjaan mahasiswa yang umumnya terdapat kesalahan terlihat pada gambar berikut

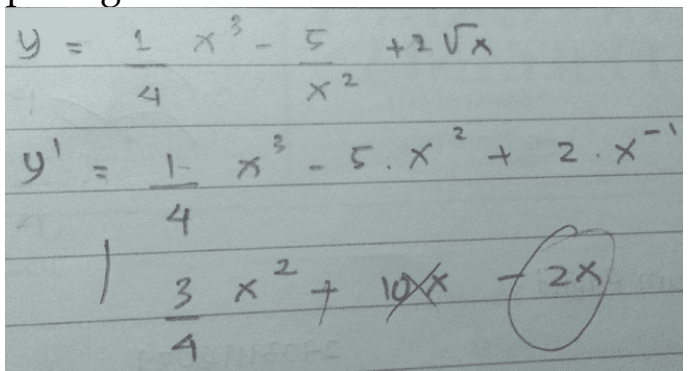

Gambar 5.

Kesalahan Jawaban Mahasiswa Soal Nomor 5

Hasil analisis soal nomor lima banyak yang mengerjakan seperti pada gambar nomor 5. Dimana mereka keliru menurunkan pada bagian $\frac{5}{\mathrm{x}^{2}}$ dan $2 \sqrt{x}$, yang harusnya dirubah dahulu ke bentuk $5 x^{-2}$ dan $5 x^{1 / 2}$ lalu diturunkan. Dari hasil ini menunjukkan bahwa mahasiswa masih kurang menguasai konsep mengenai teori sifatsifat perpangkatan dan bentuk akar.

Terlihat dari hasil bahwa mahasiswa kurang dalam konsep matematika seperti konsep bilangan desimal, konsep sistem bilangan riil, konsep perpengkatan, konsep turunan dengan definisi limit fungsi dan konsep turunan. Sedangkan dalam hal prinsip kelemahan mereka terlihat dalam menghubungkan konsep bilangan irasional dengan konsep domain fungsi, menghubungkan bilangan desimal dengan konsep bilangan pecahan, konsep limit dengan turunan.

Hasil ini mirip dengan penelitian yang dilakukan mutaqin [4] bahwa yang menyebakan mahasiswa kesulitan dalam mengikuti mata kuliah kalkulus 1 (1) kurang mampu dalam operasi pengurangan fungsi, (2) kurang mampu dalam operasi suku sejenis pecahan (3) kurang mampu dalam operasi suku sejenis biasa, (4) kurang mampu dalam operasi pecahan

Copyright $(20 \mathrm{xx}$, Jurnal THEOREMS (The Original Research of Mathematics) p-ISSN: 2528-102X, e-ISSN: 2541-4321, URL: http://jurnal.unma.ac.id/index.php/th 
campuran, (5) kurang mampu dalam operasi penjumlahan fungsi. Hasil penelitian lainnya oleh Nurhikmayati [5] bahwa kesulitan mahasiswa dalam menyelesaikan soal pada mata kuliah Matematika Dasar diantaranya kesulitan pada penggunaan konsep dan prinsip matematika.

\section{KESIMPULAN}

Berdasarkan hasil penelitian dan pembahasan. Ada beberapa poin yang dapat di jadikan kesimpulan yaitu :

1. Mahasiswa kesulitan dalam merubah desimal kedalam pecahan karena kurangnya pemahaman terhadap materi dan lemahnya konsep dasar matematika seperi perkalian puluhan dengan desimal.

2. Mahasiswa kurang memahami sifat-sifat perpangkatan dan bilangan irasional. Dalam menyelesaikan masalah mengenai domain dan range fungsi.

3. Lemahnya konsep turunan dengan menerapkan definisi limit fungsi.

4. Mahasiswa keliru dalam menentukan rumus turunan antara turunan perkalian dengan turunan pembagian.

5. DAFTAR PUSTAKA

[1] NCTM.(2000). Principles and standars for school mathematics. USA: The National Council of Teachers of Mathematics, Inc.

[2] Abdul Halim Fathani. (2009). Matematika Hakikat dan Logika. Yogyakarta: Ar-Ruzz Media.

[3] Widdiharto, Rachmadi. (2008). Diagnosis Kesulitan Belajar Matematika SMP dan Alternatif Proses Remidinya. Yogyakarta: Pusat Pengembangan dan
Pemberdayaan Pendidik dan Tenaga Kependidikan Matematika.

[4] Mutakin. (2012). Analisis Kesulitan Belajar Kalkulus 1 Mahasiswa Teknik Informatika: Design Research in Indonesia. Jurnal Formatif 3(1): 4960.

[5] Nurhikmayati, Iik (2017). Analisis Kesulitan Belajar Mahasiswa pada Matakuliah Matematika Dasar. UNMA : Jurnal THEOREMS Vol. 2 No. 1, Juli 2017, hal. 74-85 